\title{
Rhizobial infection in Adesmia bicolor (Fabaceae) roots
}

\section{Luciana Bianco}

\section{Archives of Microbiology}

ISSN 0302-8933

Arch Microbiol

DOI 10.1007/s00203-014-1004-0

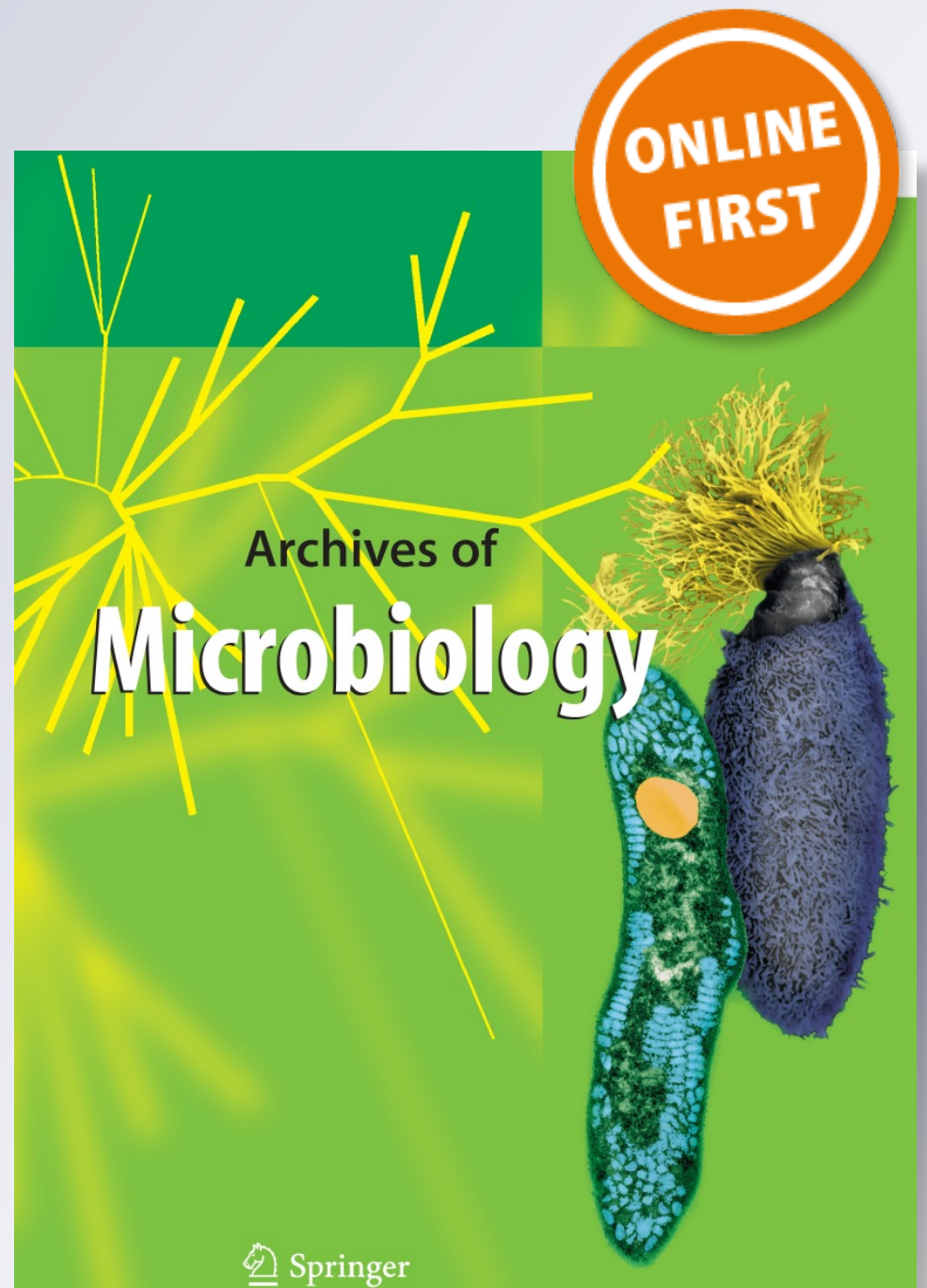

Springer 
Your article is protected by copyright and all rights are held exclusively by SpringerVerlag Berlin Heidelberg. This e-offprint is for personal use only and shall not be selfarchived in electronic repositories. If you wish to self-archive your article, please use the accepted manuscript version for posting on your own website. You may further deposit the accepted manuscript version in any repository, provided it is only made publicly available 12 months after official publication or later and provided acknowledgement is given to the original source of publication and a link is inserted to the published article on Springer's website. The link must be accompanied by the following text: "The final publication is available at link.springer.com". 


\title{
Rhizobial infection in Adesmia bicolor (Fabaceae) roots
}

\author{
Luciana Bianco
}

Received: 7 August 2013 / Accepted: 7 June 2014

(C) Springer-Verlag Berlin Heidelberg 2014

\begin{abstract}
The native legume Adesmia bicolor shows nitrogen fixation efficiency via symbiosis with soil rhizobia. The infection mechanism by means of which rhizobia infect their roots has not been fully elucidated to date. Therefore, the purpose of the present study was to identify the infection mechanism in Adesmia bicolor roots. To this end, inoculated roots were processed following conventional methods as part of our root anatomy study, and the shape and distribution of root nodules were analyzed as well. Neither root hairs nor infection threads were observed in the root system, whereas infection sites-later forming nodules-were observed in the longitudinal sections. Nodules were found to form between the main root and the lateral roots. It can be concluded that in Adesmia bicolor, a bacterial crack entry infection mechanism prevails and that such mechanism could be an adaptive strategy of this species which is typical of arid environments.
\end{abstract}

Keywords Adesmia bicolor $\cdot$ Rhizobia $\cdot$ Infection mechanism $\cdot$ Native legume

\section{Introduction}

It has been estimated that about $90 \%$ of legumes are nodulated by Rhizobium. Nodulation is typically observed in Mimosoideae (96\%) and Papilionoideae (96\%), the two

Communicated by Ursula B Priefer.

L. Bianco $(\bowtie)$

Laboratorio de Morfología Vegetal, Facultad de Agronomía y

Veterinaria, Universidad Nacional de Río Cuarto, 5800 Río

Cuarto, Provincia de Córdoba, Argentina

e-mail: lbianco@ayv.unrc.edu.ar major subfamilies of the Leguminosae. It is not so common in the Caesalpinioideae subfamily, of which only $22 \%$ of its species have been reported to be nodulating (Sprent 2009). Nodulation involves the coordination of two processes, namely an infection process and an organogenic process, the latter being a nodule development process. Infection may occur either via infection threads (ITs) in root hairs or via a crack entry mechanism (Fraysse et al. 2003; Tajima et al. 2008; Masson-Boivin et al. 2009; Madsen et al. 2011; Oldroyd et al. 2011). The host-symbiont signal exchange is initiated by the secretion of rhizobia-sensed root exudates, such as flavonoids. In response to such secretion, rhizobia synthesize lipochitooligosaccharides known as Nod factors (NFs). The latter trigger several changes in the root system including root hair deformation (due to calcium influx) and initiation of cell division in the root cortex. Rhizobia entrapped in curled root hairs form an infection pocket from which ITs begin to emerge and penetrate into the root cortex. Simultaneously, the underlying root cortex cells begin to divide by mitosis to form a nodule primordium. Within the nodule, rhizobia differentiate into bacteroids that can be found either individually or in groups and are called symbiosomes (Goormachtig et al. 2004; Oldroyd and Downie 2008; Gresshoff et al. 2009; MassonBoivin et al. 2009; Held et al. 2010; Desbrosses and Stougaard 2011; Oldroyd et al. 2011; Guan et al. 2013; Udvardi and Poole, 2013). This infection mechanism occurs in members of the three subfamilies of legumes, namely Caesalpinioideae, Mimosoideae and Papilionoideae, the latter of which includes important crops, such as Medicago sativa, Glycine max, Phaseolus vulgaris and Pisum sativum as well as other species, such as Medicago truncatula and Lotus japonicum (Wood and Newcomb 1989; Sprent 2001; Goormachtig et al. 2004; Capoen et al. 2005; Jones et al. 2007; Guan et al. 2013). 
On the other hand, in the crack entry infection mechanism, rhizobia initiate infection in damaged areas as a result of the emergence of lateral or adventitious roots. Bacteria penetrate and invade the intercellular spaces, colonizing subepidermal tissues in the root cortex (Den Herder et al. 2006; Oldroyd and Downie 2008). In some cases, it has been observed that some cortical cells therefore die as a result of the action of NFs, giving rise to the formation of infection pockets which are colonized by bacteria and which seem to have functions similar to those of the infection site in root hairs. These infection pockets allow ITs to grow and guide bacteria inside the primary nodule D'Haeze et al. 2003; Goormachtig et al. 2004). Crack entry infection occurs in some tropical legumes, such as Sesbania rostrata, Arachis hypogaea, Trifolium repens, Stylosanthes and Aeschynomene, all belonging to the Papilionoideae subfamily, and Neptunia spp. which belongs to the Mimosoideae subfamily (James et al. 1992; Goormachtig et al. 1998; D'Haeze et al. 2003; Tajima et al. 2008).

In view of the above, the aim of this study was to investigate how infection is spread in Adesmia bicolor roots. Adesmia bicolor, a native legume with forage potential and high efficiency in nitrogen fixation, has the ability to adapt itself to limiting environmental conditions (Basconsuelo et al. 1997; Malpassi et al. 1999; Weberling et al. 2002; Bianco and Kraus 2005; Vileta et al. 2010). Although previous research has already been conducted on the diversity and effectiveness of native rhizobia nodulating this legume (Bianco et al. 2012), it would be interesting to further explore which is the bacterial infection mechanism that prevails in Adesmia bicolor.

\section{Materials and methods}

Plant growth and infection

Seeds of Adesmia bicolor were collected at the Universidad Nacional de Río Cuarto, Córdoba province, Argentina $\left(33^{\circ} 05^{\prime} \mathrm{S}, 64^{\circ} 20^{\prime} \mathrm{W}\right)$. They were mechanically scarified and sterilized with ethanol for $1 \mathrm{~min}$, with $6 \%$ sodium hypochlorite for $3 \mathrm{~min}$ and exhaustively washed in five changes of autoclaved distilled water. They were then kept at $30{ }^{\circ} \mathrm{C}$ until germination. After seed germination, they were put on sterile plates containing culture medium with the nutrients needed for plant growth $\left[\mathrm{CaCl}_{2} \cdot 2 \mathrm{H}_{2} \mathrm{O}, \mathrm{K}_{2} \mathrm{HPO}_{4}, \mathrm{KH}_{2} \mathrm{PO}_{4}, \mathrm{Fe}\right.$-Citrat, $\mathrm{MgSO}_{4} \cdot 7 \mathrm{H}_{2} \mathrm{O} \mathrm{K} \mathrm{KO}_{4}, \mathrm{MnSO}_{4} \cdot \mathrm{H}_{2} \mathrm{O}, \mathrm{ZnSO}_{4} \cdot 7 \mathrm{H} 2 \mathrm{O}$, $\mathrm{H}_{3} \mathrm{BO}_{3}, \quad \mathrm{CuSO}_{4} \cdot 5 \mathrm{H}_{2} \mathrm{O}, \quad \mathrm{CoSO}_{4} \cdot 7 \mathrm{H}_{2} \mathrm{O} \quad\left(\mathrm{CoCl}_{2} \cdot 6 \mathrm{H}_{2} \mathrm{O}\right)$, $\mathrm{Na}_{2} \mathrm{MoO}_{4} \cdot 2 \mathrm{H}_{2} \mathrm{O}$ ]. Plantlets were inoculated with strains isolated from nodules and were kept in growth chambers at $28{ }^{\circ} \mathrm{C}$ under 12 -h light/12-h darkness conditions until nodule emergence.
Morphological and anatomical studies of root system and nodules

Forty days after inoculation with rhizobial strains, nodule shape and distribution were analyzed. In addition, for the anatomical study, roots were fixed in FAA (ethanol:acetic acid:formaldehyde, 50:5:30:15), dehydrated in an ethyl alcohol-xylol series and embedded in Histowax. Cross and longitudinal serial sections were cut at $10 \mu \mathrm{m}$ and stained with safranin-fast green (Dizeo de Strittmater 1979; D'Ambrogio de Argüeso 1986). Histological slides were analyzed and photographed with an Axiophot Zeiss microscope with Axiovision software and an Axiocam HRC Zeiss camera.

\section{Results}

An important feature observed in the present study was the absence of root hairs and ITs both in the cross and longitudinal serial sections of the root epidermis (Fig. 1a). The entry of rhizobia was observed to occur through a fissure caused by the emergence of lateral roots. In the longitudinal sections, cortical cells were found to divide themselves repeatedly, giving rise to several daughter cells, where bacteria distributed themselves, thus forming what is known as the "infection site." Uninfected cells surrounding this area were observed to divide at the same time, and infection sites were found to form between the main root and the lateral roots, thus giving rise to the primordial nodule (Fig. 1b). In the primordial nodule, two regions could be observed, namely the cortex zone and the bacterial zone. The latter, which was initially reduced, was found located in the center of the nodule showing a few uninfected and infected cells, both with a specific function in nitrogen assimilation (Fig. 1c). The bacterial zone was found to be occupied by isodiametric parenchyma cells having a centrally located and generally visible nucleus. In the adult nodules, the root cortex was observed to be subdivided into several layers of cortical parenchyma and vascular bundles surrounding the infection site, whose function is to irrigate the nodule, as well as the meristematic zone, were also observed. The bacterial zone was found to be discontinuous and subdivided into regions separated by parenchyma cells (Fig. 1d). Nodule emergence was observed to begin 2 weeks after planting. Nodules, which were found to be oblong in shape and with determinate growth, grew between the main root and the lateral roots (Fig. 1e, f). In general, they were observed to be distributed in pairs and they increased in number as the plant grew. Initially, the majority of them were found in the main root rather than in the lateral roots. A red 

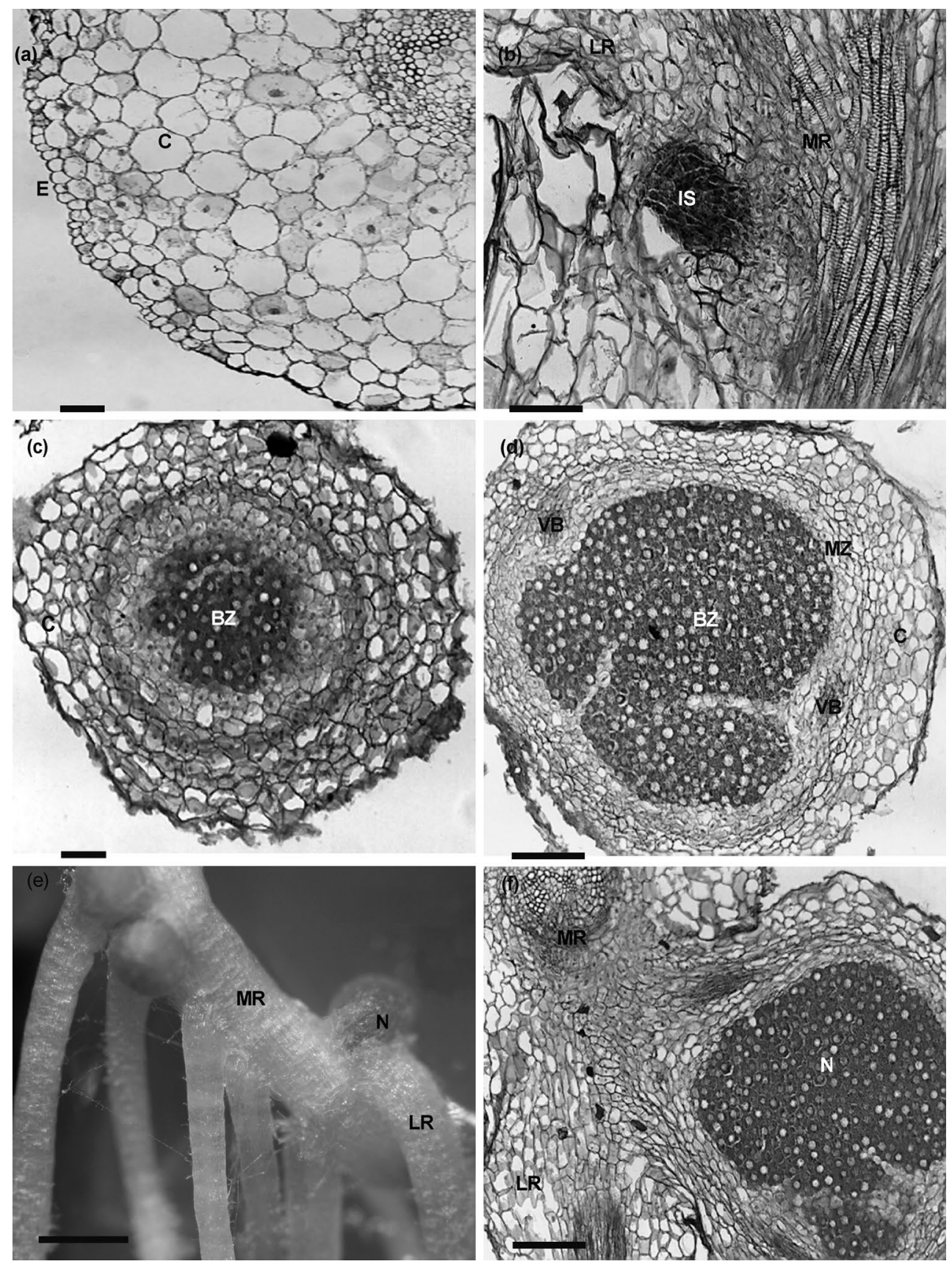

Fig. 1 Anatomical characters of Adesmia bicolor root and nodule. a Cross section of the main root showing the root epidermis. b Longitudinal root section showing an infection site. $\mathbf{c}$ Cross section of a primordial nodule showing a growing bacterial zone. $\mathbf{d}$ Cross section of an adult nodule showing the cortex, vascular bundles, meristematic zone and discontinuous bacterial zone. e. Plantlets showing nodules

color was observed inside the nodules, which is indicative of the presence of leghemoglobin, which, in turn, indicates that Rhizobium sp. strains are efficient. Taken together, all these observations are indicative of a bacterial crack entry infection mechanism in Adesmia bicolor roots. between the main root and the lateral roots. $\mathbf{f}$ Cross section showing nodules between the main root and the lateral roots. Abbreviations: $E$ epidermis, $C$ cortex, $I S$ infection site, $M R$ main root, $L R$ lateral root, $B Z$ bacterial zone, $V B$ vascular bundle, $M Z$ meristematic zone, $N$ nodule. Scale bars 100, 250 and $3 \mathrm{~mm}$

\section{Discussion}

Although literature findings indicate that the most common infection mechanism in Rhizobium is through root hairs, a crack entry mode of infection has been observed in $75 \%$ of the species belonging to the subfamily Papilionoideae. 
In this type of infection mechanism, IT formation is not necessary as Rhizobium infects the roots through either a fissure caused by the emergence of lateral roots or a lesion directly produced on the root epidermis (Sprent 2007; Noisangiama et al. 2012). Therefore, the absence of root hairs and ITs in Adesmia bicolor is indicative of a bacterial crack entry infection mode in this species. Furthermore, in agreement with observations of other legume species, such as Arachis, Stylosanthes and Aeschynomene (Chandler et al. 1982; Sprent 2001; Sprent and James 2007), in the present study, it could be observed that nodules form between the main root and the lateral roots.

On the other hand, although the description of Adesmia bicolor nodules mostly agrees with data from Rothschild's research (1963), some differences were detected in the present study, e.g., those related to the division zone. In this respect, Rothschild (1963) claims that there are four division zones while in the present study, which was carried out following Vance's (2002) description of nodules, only two division zones were observed. Adult nodules were also found to show a discontinuous bacterial area which was separated by parenchyma cells in agreement with a study carried out in Adesmia araujoi by Scheffer-Basso et al. (2000). In line with this, the presence of uninfected cells in the bacterial infection site and a crack entry infection mode with absence of ITs are both characteristic of aeschynomenoid nodules (Sprent and James 2007). The latter are oblong in shape, with determinate growth, and are, in general, associated with an adventitious or lateral root. All the nodules belonging to the Aeschynomeneae tribe studied to date along with genera of the tribe Dalbergieae (Centrolobium, Dalbergia, Etaballia, Geoffroea, Machaerium, Platymiscium, Platypodium, Riedeliella, Tipuana and Pterocarpus), Abreae, Phaseoleae and Robinieae fit this description. Further studies, though not so numerous as those conducted on the above-mentioned genera, also show the presence of aeschynomenoid root nodules in Adesmia, Brya and Cranocarpus (Corby 1981; Sprent et al. 1989; Lavín et al. 2001; Guinel 2009).

\section{References}

Basconsuelo S, Malpassi R, Kraus T, Bianco C, Weberling F (1997) Growth forms of species of Galactia genus (Leguminosae) in southern Córdoba province. Argentina. Beitr Biol Pflanzen 70:1-13

Bianco CA, Kraus TA (2005) Desarrollo y estructura de la semilla y el fruto de Adesmia bicolor (Poir.). DC. (Fabaceae). Phyton 54:71-77

Bianco L, Angelini J, Fabra A, Malpassi R (2012) Diversity and symbiotic effectiveness of indigenous rhizobia-nodulating Adesmia bicolor in soils of central Argentina. Curr Microbiol 66:174-184. doi:10.1007/s00284-012-0260-y

Capoen W, Goormachtig S, De Rycke R, Schroeyers K, Holsters M (2005) SrSymRK, a plant receptor essential for symbiosome formation. Plant Biol 102:10369-10374
Chandler MR, Date RA, Roughley RJ (1982) Infection and root-nodule development in Stylosanthes species by Rhizobium. J Exp Bot 33:47-57

Corby HDL (1981) The systematic value of leguminous root nodules. In: Polhill RM, Raven PH (eds) Advances in legume systematic. Royal Botanic Gardens, Kew, pp 657-669

D’Ambrogio de Argüieso A (1986) Manual de técnicas en histología vegetal. Hemisferio Sur, Buenos Aires, p 83

D’Haeze W, De Rycke R, Mathis R, Goormachtig S, Pagnotta S, Verplancke C, Capoen W, Holsters M (2003) Reactive oxygen species and ethylene play a positive role in lateral root base nodulation of a semi-aquatic legume. Proc Natl Acad Sci USA 100:11789-11794

Den Herder G, Schroeyers K, Holsters M, Goormachtig S (2006) Signaling and gene expression for water-tolerant legume nodulation. CRC Crit Rev Plant Sci 25:367-380

Desbrosses GJ, Stougaard J (2011) Root nodulation: a paradigm for how plant-microbe symbiosis influences host developmental pathways. Cell Host Microbe 10:348-358. doi:10.1016/j.chom.2011.09.005

Dizeo de Strittmater C (1979) Modificación de una técnica de colaboración safranina-fast green. Biol Soc Arg Bot 18:121-122

Fraysse N, Couderc F, Poinsot V (2003) Surface polysaccharide involvement in establishing the Rhizobium-legume symbiosis. Eur J Biochem 270:1365-1380

Goormachtig S, Lievens S, Van de Velde W, Van Montagu M, Holsters M (1998) The symbiotic interaction between Azorhizobium caulinodans and Sesbania rostrata. Molecular crosstalk in a beneficial plant bacterium interaction. Sub-Cell Biochem 29:117-164

Goormachtig S, Capoen W, Holsters M (2004) Rhizobium infection: lessons from the versatile nodulation behaviour of water-tolerant legumes. Trends Plant Sci 9:518-522

Gresshoff PM, Lohar D, Chan PK, Biswas B, Jiang Q, Reid D, Ferguson B, Stacey G (2009) Genetic analysis of ethylene regulation of legume nodulation. Plant Signal Behav 4:818-823

Guan D, Stacey N, Liu C, Wen J, Mysore KS, Torres-Jerez I, Vernié T, Tadege M, Zhou C, Wang Z, Udvardi MK, Oldroyd GED, Murray JD (2013) Rhizobial infection is associated with the development of peripheral vasculature in nodules of Medicago truncatula. Plant Physiol 162:107-115

Guinel FC (2009) Getting around the legume nodule: I. Molecular biology of its peripheral zone in four nodule types. Botany 87:1117-1138

Held M, Hossain MS, Yokota K, Bonfante P, Stougaard J, Szczyglowski K (2010) Common and not so common symbiotic entry. Trends Plant Sci 15:540-545

James EK, Sprent JI, Sutherland JM, Mcinroy SG, Minchin FR (1992) The structure of nitrogen fixing root nodules on the aquatic mimosoid legume Neptunia plena. Ann Bot 69:173-180

Jones KM, Kabayashi H, Davies BW, Taga ME, Walker GC (2007) How rhizobial symbionts invade plants: the Sinorhizobium-Medicago model. Nat Rev Microbiol 5:619-633

Lavin M, Pennington RT, Klitgaard BB, Sprent JI, Cavalcante De Lima H, Gasson PE (2001) The dalbergioid legumes (Fabaceae): delimitation of a pantropical monophyletical clade. Am J Bot 88:503-533

Madsen EB, Antolín-Llovera M, Grossmann C, Ye J, Vieweg S, Broghammer A, Krusell L, Radutoiu S, Jensen ON, Stougaard J, Parniske M (2011) Autophosphorylation is essential for the in vivo function of the Lotus japonicas Nod factor receptor 1 and receptor-mediated signaling in cooperation with Nod factor receptor 5. Plant J 65:404-417

Malpassi R, Hampp E, Bianco C, Basconsuelo B, Grosso M, Kraus T (1999) Anatomía de raíces de Arachis hypogaea L. en parcelas encaladas. Rev UNRC 19:19-26 
Masson-Boivin C, Giraud E, Perret X, Batut J (2009) Establishing nitrogen-fixing symbiosis with legumes: how many Rhizobium recipes? Trends in Microbiol 17:458-466

Noisangiama R, Teamtisongb K, Tittabutra P, Boonkerda N, Toshikic U, Minamisawad K, Teaumroonga N (2012) Genetic diversity, symbiotic evolution, and proposed infection process of Bradyrhizobium strains isolated from root nodules of Aeschynomene americana L. in Thailand. Appl Environ Microbiol 78:6236-6250

Oldroyd GED, Downie JA (2008) Coordinating nodule morphogenesis with rhizobial infection in legumes. Annu Rev Plant Biol 59:519-546. doi:10.1146/annurev.arplant.59.032607.092839

Oldroyd GED, Murray JD, Poole PS, Downie JA (2011) The rules of engagement in the legume-rhizobial symbiosis. Annu Rev Genet 45:119-144

Rothschild DI (1963) Anatomía del nódulo radical de las leguminosas cultivadas. Rev. Instituto Municipal de Botánica de Jardín Botánico. Carlos Thays 3:1-32

Scheffer-Basso SM, Carneiro CM, Voss M (2000) Nodulação e fixação biológica de nitrogênio em Adesmia araujoi Burk. Rev Bras Agroc 6:16-18

Sprent JI (2001) Nodulation in legumes. Royal Botanical Gardens, Kew

Sprent JI (2007) Evolving ideas of legume evolution and diversity: a taxonomic perspective on the occurrence of nodulation. New Phytol 174:11-25

Sprent JI (2009) Legume nodulation. In: Wiley-Blackwell (ed). A global perspective. Oxford, UK, pp 183
Sprent JI, James EK (2007) Legume evolution: where do nodules and mycorrhizas fit in? Plant Physiol 144:575-581

Sprent JI, Sutherland M, De Faria SM (1989) Structure and function of root nodules from woody legumes. In: Stirton $\mathrm{CH}$, Zarucchi JL (eds). Advances in legume biology. Monogr. Syst Bot Mo Bot Gard. 29:559-578

Tajima R, Abe J, Lee ON, Morita S, Lux A (2008) Developmental changes in peanut root structure during root growth and rootstructure modification by nodulation. Ann Bot 101:491-499

Udvardi M, Poole PS (2013) Transport and metabolism in legume-rhizobia symbioses. Annu Rev Plant Biol 64:781-805. doi:10.1146/annurev-arplant-050312-120235

Vance CP (2002) Root-bacteria interactions: symbiotic $\mathrm{N}_{2}$ fixation. In: Waisel Y, Eshel A, Kafkafi U (eds) Plant roots. The hidden half, 3rd edn. Marcel Dekker Inc, New York, pp 839-868

Vileta D, Bianco L, Grosso M, Malpassi R (2010) Biological nitrogen fixation by Adesmia bicolor and A. macrostachya, potential forage species for arid and semi-arid environments. Interciencia 35:120-125

Weberling F, Kraus TA, Bianco CA, Malpassi M (2002) Variación y estrategias adaptativas de los sistemas de ramificación de Fabáceas herbáceas. Feddes Repert 113:342-353

Wood SM, Newcomb W (1989) Nodule morphogenesis: the early infection of alfalfa (Medicago sativa) root hairs by Rhizobium meliloti. Can J Bot 67:3108-3122 